\title{
The Ins and Outs of Cellular $\mathrm{Ca}^{2+}$ Transport
}

\author{
Edgar P. Spalding ${ }^{1}$ and Jeffrey F. Harper ${ }^{2}$ \\ Edgar P. Spalding: spalding@wisc.edu; Jeffrey F. Harper: jharper@unr.edu \\ ${ }^{1}$ Edgar P. Spalding, University of Wisconsin-Madison, Department of Botany, 430 Lincoln Drive, \\ Madison, WI 53706, phone: +1-608-265-5294, fax +1-608-262-7509 \\ 2Jeffrey F. Harper, University of Nevada, Reno, Biochemistry Department MS-330, 220 Howard \\ Building, Reno, NV 89557, USA, phone: +1-775-784-1349, fax: +1-775-784-1286
}

\begin{abstract}
The cytoplasmic $\mathrm{Ca}^{2+}$ signals that participate in nearly all aspects of plant growth and development encode information as binary switches or information-rich signatures. They are the result of influx (thermodynamically passive) and efflux (thermodynamically active) activities mediated by membrane transport proteins. On the influx side, confirming the molecular identities of $\mathrm{Ca}^{2+}$-permeable channels is still a major research topic. Cyclic nucleotide-gated channels and glutamate receptor-like channels are candidates well supported by evidence. On the efflux side, CAX antiporters and P-type ATPase pumps are the principal molecular entities. Both of these active transporters load $\mathrm{Ca}^{2+}$ into specific compartments and have the potential to reduce the magnitude and duration of a $\mathrm{Ca}^{2+}$ transient. Recent studies indicate calmodulin-activated $\mathrm{Ca}^{2+}$ pumps in endomembrane systems can dampen the magnitude and duration of a $\mathrm{Ca}^{2+}$ transient that could otherwise grow into a $\mathrm{Ca}^{2+}$ cell-death signature. An important challenge following molecular characterization of the influx and efflux pathways is to understand how they are coordinately regulated to produce a $\mathrm{Ca}^{2+}$ switch or encode specific information into a $\mathrm{Ca}^{2+}$ signature.
\end{abstract}

\section{Introduction}

Some chemical facts match calcium well with the signaling functions it performs throughout plant biology. It is the third most abundant metal in the Earth's crust and it readily forms a precipitate with phosphate. To avoid precipitation of the sparingly soluble $\mathrm{Ca}_{3}\left(\mathrm{PO}_{4}\right)_{2}$ in the cytoplasm, a low cytosolic free $\mathrm{Ca}^{2+}$ concentration (e.g., $\left.<0.1 \mu \mathrm{M}\right)$ must be maintained despite a thousand-fold higher external concentration and a very negative membrane potential (e.g., $<-180 \mathrm{mV}$ ). The resulting inward-directed electrochemical potential difference for $\mathrm{Ca}^{2+}$ across the plasma membrane $\left(\Delta \mu_{\mathrm{Ca}}\right)$ is $-52 \mathrm{~kJ} \mathrm{~mol}^{-1}$ given these typical values, meaning that $\mathrm{Ca}^{2+}$ may flow into the cytoplasm through passive transporters such as ion channels without breaking any rules. It also means $\mathrm{Ca}^{2+}$ must be pumped up a $52 \mathrm{~kJ}$ $\mathrm{mol}^{-1}$ 'hill' in order to move out. To put this hill in perspective, the free energy $(\Delta \mathrm{G})$ of ATP hydrolysis is $-49 \mathrm{~kJ} \mathrm{~mol}^{-1}$ in a typical cellular condition. The same thermodynamic analysis applied to membranes bounding other cellular compartments shows that with respect to the cytoplasm, IN is always 'downhill', and OUT is always 'uphill'.

Publisher's Disclaimer: This is a PDF file of an unedited manuscript that has been accepted for publication. As a service to our customers we are providing this early version of the manuscript. The manuscript will undergo copyediting, typesetting, and review of the resulting proof before it is published in its final citable form. Please note that during the production process errors may be discovered which could affect the content, and all legal disclaimers that apply to the journal pertain. 
A transient rise in cytosolic free $\mathrm{Ca}^{2+}$ concentration that can function as an intracellular signal is generated when influx temporarily exceeds efflux. Two models have been proposed to explain how a transient change in concentration of a single ion can regulate so many aspects of plant development, including abiotic and biotic stress responses, tip growth, and gravitropism [1]. In a " $\mathrm{Ca}^{2+}$ signature" model, variations in a $\mathrm{Ca}^{2+}$ transient's magnitude, duration, and/or repetition frequency are proposed to encode specific information that activate or inhibit different signal transduction networks. In a simple switch model [1], $\mathrm{Ca}^{2+}$ transients with different shapes all function in an equivalent fashion as simple switch. The key distinction is that specific information in a $\mathrm{Ca}^{2+}$ switch is not encoded through the complexity of the message, but rather lies in the unique status of the receiver. Both models are likely relevant to different signaling pathways in plants. At the core of both models is the subject of this review - proteins that transport $\mathrm{Ca}^{2+}$ uphill and downhill across membranes to create and shape $\mathrm{Ca}^{2+}$ transients [2,3].

\section{Influx: Taking stock of the paths}

\section{Cyclic nucleotide-gated channels - CNGC}

A calmodulin-binding protein isolated from barley aleurone was discovered to be homologous with animal cyclic nucleotide-gated ion channels (CNGCs), displaying six membrane-spanning helices, a pore-forming loop, and separate cyclic nucleotide- and calmodulin-binding domains in the carboxy terminus [4,5]. Animal CNGCs function as nonselective cation channels, transporting primarily $\mathrm{K}^{+}, \mathrm{Na}^{+}$, and $\mathrm{Ca}^{2+}$ in olfactory and light sensing systems. A mutation in one of the 20 Arabidopsis CNGCs (AtCNGC2) was found to impair the hypersensitive response to a pathogenic bacterium [6]. Three other members of the family were subsequently found to participate in the same process [7], which is known to involve rapid fluxes of ions including $\mathrm{Ca}^{2+}$ across the plasma membrane. However, relationship to animal CNGCs is not sufficient evidence to conclude that the pathogenassociated ion fluxes in plants are CNGC-mediated because the amino acid sequence of the pore region, which determines ion specificity, is GETP in animals and ANDL in AtCNGC2 [5]. Other AtCNGCs are no closer to the animal sequence in the pore region [8].

Heterologous expression studies provide the most direct evidence for $\mathrm{Ca}^{2+}$ transport activity for particular CNGCs. Human embryonic kidney cells expressing AtCNGC2 display a rise in cytoplasmic $\mathrm{Ca}^{2+}$ concentration after cyclic nucleotide treatment [9], and E. coli cells expressing CNGC18 accumulated higher levels of $\mathrm{Ca}^{2+}$ than controls [10]. Lack of a cyclicnucleotide-gated $\mathrm{Ca}^{2+}$ current across mutant guard cell plasma membranes further supported $\mathrm{a} \mathrm{Ca}^{2+}$ transport function for AtCNGC2 [11]. Likewise, root apices of antisense plants underexpressing AtCNGC10 display reduced $\mathrm{Ca}^{2+}, \mathrm{Mg}^{2+}$, and $\mathrm{H}^{+}$influx [12].

\section{Glutamate receptor-like channels - GLR}

During the Arabidopsis genome sequencing effort, genes homologous with mammalian ionontropic glutamate receptors (iGluRs) were identified [13,14]. Like CNGCs, iGluRs form ligand-gated channels that transport $\mathrm{Na}^{+}, \mathrm{K}^{+}$, and $\mathrm{Ca}^{2+}$ to varying degrees, depending on subunit composition [15]. Unlike CNGCs, the ligand-binding domain is extracellular in iGluRs. In plant cells, exogenous amino acids trigger a large, transient rise in cytoplasmic $\mathrm{Ca}^{2+}$ concentration and a resultant plasma membrane depolarization, consistent with the idea that plant GLRs function similarly to iGluRs $[16,17]$. However, none of the 20 AtGLRs has a pore sequence similar to an iGluR [18], again giving reason not to accept a similar function without experimental evidence. Such evidence is accumulating. Replacement of the pore region of an animal iGluR with that of AtGLR1.1 or AtGLR1.4 produced channels capable of transporting $\mathrm{Na}^{+}, \mathrm{K}^{+}$, and $\mathrm{Ca}^{2+}$ when expressed in Xenopus oocytes [19]. Plantbased studies showed that mutants lacking AtGLR3.3 do not display the large, transient membrane depolarization that ala, asn, cys, gly, glu, or ser trigger in the wild type, or the 
associated rises in cytoplasmic $\mathrm{Ca}^{2+}$ [20]. A related study showed that hypocotyl cells of glr3.4 mutants respond normally to ala, cys, and glu, but less well to asn, gly, and ser, indicating variation in agonist specificity among GLRs and that co-expressed subunits may form heteromeric channels in planta [21,22]. Pollen tubes lacking GLR1.2 were shown to display aberrant oscillations in cytoplasmic $\mathrm{Ca}^{2+}$ concentration associated with an amino acid, in this case D-ser [23]. Still needed before GLRs can be considered $\mathrm{Ca}^{2+}$-conducting channels is a functional demonstration of this activity in a heterologous system. Attempts with AtGLR3.7 expressed in Xenopus oocytes failed to produce an amino-acid gated activity like those observed in the plant [22].

\section{Mid1 complementing activities - MCA}

Yeast lacking Mid1-dependent channels are defective in $\mathrm{Ca}^{2+}$ transport across the plasma membrane. Two Arabidopsis genes can complement the midl $\mathrm{Ca}^{2+}$ uptake defect, though the Midl complementing activities (MCA1 and MCA2) are not related to the Midl gene or to any other functionally characterized protein $[24,25]$. Evidence from plant and heterologous expression studies indicate MCA1 and MCA2 mediate $\mathrm{Ca}^{2+}$ uptake across the plasma membrane, particularly in cells experiencing mechanical stress from excessive turgor pressure or touch. Unlike the previous examples, no model channel exists to guide hypotheses about ion selectivity or other functional aspects. An electrophysiological study in a heterologous expression system would be very valuable.

\section{Two pore channels - TPC}

The vacuole is a potential source of $\mathrm{Ca}^{2+}$ for release to the cytoplasm, and various studies show that it can do so [26]. The best candidate for a vacuolar $\mathrm{Ca}^{2+}$ release channel is TPC1, a homolog of a mammalian voltage-gated $\mathrm{Ca}^{2+}$ channel that possesses two pores and twelve membrane spans. The AtTPC1 pore region is very similar to its $\mathrm{Ca}^{2+}$-conducting animal homolog and it possesses $\mathrm{Ca}^{2+}$-binding EF-hands [27]. Thus, its structure is consistent with it mediating the $\mathrm{Ca}^{2+}$-activated, nonselective cation currents characteristic of the wild-type tonoplast $[28,29]$. Experimental evidence strongly supports the case. AtTPC1 was shown to mediate $\mathrm{Ca}^{2+}$ uptake in yeast [30], and tpcl tonoplasts do not display the aforementioned currents [31]. However, the important demonstration of $\mathrm{Ca}^{2+}$ conductance encoded by TPC1 in a heterologous expression system has not yet been reported and its activity has not yet been shown to generate a cytoplasmic $\mathrm{Ca}^{2+}$ signal $[32,33]$. Patch clamping of yeast plasma membranes containing AtTPC1 may address the former and more single-cell studies of cytosolic $\mathrm{Ca}^{2+}$ transients in $t p c 1$ mutants may address the latter, particularly if performed in guard cells where TPC1 activity and physiological function are pronounced [33,34].

\section{Activities requiring molecular identification}

Electrophysiological studies of the plasma membrane have shown inward $\mathrm{Ca}^{2+}$ currents activated at increasingly negative (hyperpolarizing) potentials, and others that are not active until the membrane becomes sufficiently depolarized [35]. In either case, influx is 'downhill' and therefore consistent with a channel for which no protein has been identified. Plant endomembranes show evidence of $\mathrm{Ca}^{2+}$ release triggered by inositol 1,4,5trisphosphate and cyclic ADP-ribose, but the molecular identity of the channels mediating these fluxes are yet unknown and plant genomes appear to lack homologs of the channels responsible for these ligand-gated endomembrane fluxes in animals [26].

\section{Eflux: Changing a "signature", or loading a compartment?}

Pumps and antiporters provide two types of energized transport systems that move $\mathrm{Ca}^{2+}$ out of the cytoplasm after a $\mathrm{Ca}^{2+}$ release. The known $\mathrm{Ca}^{2+}$ antiporters all belong to a family of CAXs ( $\mathrm{Ca}^{2+}$ exchangers), which in some cases have been shown to exchange $\mathrm{Ca}^{2+}$ for a 
counter ion such as $\mathrm{H}^{+}$[36]. With antiporters, the downhill movement of the counter ion provides the driving force for $\mathrm{Ca}^{2+}$ transport. CAXs are considered high capacity, low affinity efflux systems. There are two types of $\mathrm{Ca}^{2+}$ pumps, ACAs (auto-inhibited $\mathrm{Ca}^{2+}$ ATPases) and ECAs (ER-type $\mathrm{Ca}^{2+}$-ATPases) belonging to a family of P-type ATPases that move ions against their concentration gradients using the energy from ATP hydrolysis [37]. These are considered low capacity, high affinity efflux systems. In addition, a Zn transporting heavy metal pump associated with the chloroplast (AtHMA1) [38] has been reported to transport $\mathrm{Ca}^{2+}[39]$. This latter example highlights that $\mathrm{Ca}^{2+}$ efflux might also occur through unexpected transport systems that have yet to be characterized.

Because pumps and antiporters have the potential to change the magnitude and duration of a $\mathrm{Ca}^{2+}$ signal, knockouts or over-activation were initially expected to reveal dramatic effects on plant growth and development. Such predictions have yet to be validated. While several interesting phenotypes have been documented, such as partial male sterility and increased sensitivities to abiotic stresses [40] there have been no reports of a "dramatic" phenotype, such as a lethal knockout. In contrast, lethal mutations have been reported in animals [41]. It is not clear if plants have more gene redundancies or alternative efflux systems, or if plants are less reliant on using efflux systems to shape specific $\mathrm{Ca}^{2+}$ signatures for essential developmental events (i.e., plants might use $\mathrm{Ca}^{2+}$ switches more than $\mathrm{Ca}^{2+}$ signatures).

In plants, genetic evidence that the information content of a $\mathrm{Ca}^{2+}$ signal can be controlled by a $\mathrm{Ca}^{2+}$ efflux system has recently emerged from three studies. Knockout of PCAl, which encodes a vacuolar $\mathrm{Ca}^{2+}$ pump in the moss Physcomitrella patens, increases the magnitude and duration of a $\mathrm{NaCl}$-triggered $\mathrm{Ca}^{2+}$ signal and decreases $\mathrm{NaCl}$ tolerance of the organism

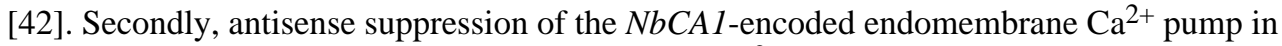
tobacco increased the magnitude and duration of a $\mathrm{Ca}^{2+}$ signal triggered by fungal or viral pathogens, or the cryptogein elicitor, and accelerated pathogen-triggered programmed cell death [43]. The third recent example comes from studying a double knockout of aca4 and 11, the two vacuolar $\mathrm{Ca}^{2+}$ pumps in Arabidopsis [44]. Knockout plants showed a high frequency of hypersensitive-like lesions (i.e., lesion mimic mutant). Lesions were dependent on salicylic acid (SA), whose production was previously shown to be regulated by $\mathrm{Ca}^{2+}$ signals $[45,46]$. The vacuoles of aca4/11 mesophyll cells in which lesions originate were shown to have normal $\mathrm{Ca}^{2+}$ levels, indicating that other transporters maintain $\mathrm{Ca}^{2+}$ loading levels [47] and that lesions result from an altered $\mathrm{Ca}^{2+}$ signal rather than vacuolar $\mathrm{Ca}^{2+}$ deficiency. $\mathrm{Ca}^{2+}$ imaging experiments in the aca4/11 double mutant are needed to assess the signal-shaping roles of these pumps.

It is important to note that phenotypes associated with $\mathrm{Ca}^{2+}$ efflux systems can have two different mechanistic origins; one by changing the dynamics of a $\mathrm{Ca}^{2+}$ transient, the other by changing the $\mathrm{Ca}^{2+}$ levels in a specific compartment (i.e. " $\mathrm{Ca}^{2+}$ nutrition"). In considering $\mathrm{Ca}^{2+}$ nutrition, increased or decreased loading of $\mathrm{Ca}^{2+}$ into a specific compartment might alter biochemical reactions or macromolecular interactions, and thereby disrupt processes such as vesicle trafficking or cell wall biogenesis $[48,49]$. Thus, changes in $\mathrm{Ca}^{2+}$ nutrition could indirectly cause many phenotypes, even in situations where $\mathrm{Ca}^{2+}$ imaging provides exciting evidence for an altered $\mathrm{Ca}^{2+}$ signature (e.g., as imaged in cells deficient in PCA1 and NbCA1). Thus, delineating the actual cause of a phenotype in an efflux mutant will always be very difficult.

Together, the death promoting phenotypes associated with reduced activities of PCA1, $\mathrm{NbCA} 1$, and ACA4/11 provide strong support for a model in which endomembrane $\mathrm{Ca}^{2+}$ pumps can function to dampen the magnitude and duration a $\mathrm{Ca}^{2+}$ signal (Figure 1). In the absence of these specific pumps, it appears that a $\mathrm{Ca}^{2+}$ transient can morph into a "cell-death $\mathrm{Ca}^{2+}$ signature". An interesting question is why don't other $\mathrm{Ca}^{2+}$ efflux pathways 
compensate for a missing pump? We offer two answers for consideration. First, location might be critical. Many $\mathrm{Ca}^{2+}$ signals are thought to be highly localized. Thus, a signal emanating from the vacuole might be too far away to be quickly sequestered by efflux systems associated with the ER (or vice versa). Second, in specific cell types under specific conditions, other efflux systems might be down-regulated, thereby blocking their ability to dampen the rise of a cell death $\mathrm{Ca}^{2+}$ signature. It is noteworthy that ACA and CAXs have known autoinhibitors [37,50], and are therefore subject to regulation that can decrease their transport activities under certain situations.

\title{
The Future - The Genesis of Switches and Signatures
}

While deficiencies in identified efflux pathways appear to potentiate the emergence of a $\mathrm{Ca}^{2+}$ cell death signature, the influx pathways that initiate those signals are yet to be defined. They could be among the above discussed transporters or among the additional $\mathrm{Ca}^{2+}$ pathways still to be discovered either through finding new candidates, new properties of proteins better known for other functions, or functions at other cellular membranes. For example, the AtSKOR and OsHKT2;4 transporters are known more as $\mathrm{K}^{+}$transporters but they also have measureable $\mathrm{Ca}^{2+}$ permeability $[51,52]$ as do the multifunctional, membrane associated annexins [53]. GLR channels may have important functions not only at the plasma membrane [54], and TPC1 may not be restricted to the tonoplast [55,56]. Identifying the various contributors to $\mathrm{Ca}^{2+}$ circuits and their localizations is necessary but the desired level of understanding will require learning how they are regulated to generate informationrich $\mathrm{Ca}^{2+}$ signatures, or simple $\mathrm{Ca}^{2+}$ switches.

\section{Acknowledgments}

This work was supported by grants to JFH from National Science Foundation (MCB-0920624) and National Institutes of Health 1RO1 GM070813-01, and Department of Energy DE-FG03-94ER20152, and by Department of Energy grant DE-FG02-10ER15527 to EPS.

\author{
Abbreviations \\ CNGC cyclic nucleotide-gated ion channels \\ GLR glutamate receptors \\ TPC two pore channel \\ CAX $\quad \mathrm{Ca}^{2+}$ exchanger \\ ACAs auto-inhibited $\mathrm{Ca}^{2+}$-ATPases \\ ECAs $\quad$ ER-type $\mathrm{Ca}^{2+}$-ATPases
}

\section{References and recommended reading}

1. Scrase-Field SA, Knight MR. Calcium: just a chemical switch? Curr Opin Plant Biol. 2003; 6:500506. [PubMed: 12972052]

2. McAinsh MR, Pittman JK. Shaping the calcium signature. New Phytol. 2009; 181:275-294. [PubMed: 19121028]

3. Dodd AN, Kudla J, Sanders D. The language of calcium signaling. Annu Rev Plant Biol. 2010; 61:593-620. [PubMed: 20192754]

4. Schuurink RC, Shartzer SF, Fath A, Jones RL. Characterization of a calmodulin-binding transporter from the plasma membrane of barley aleurone. Proc Natl Acad Sci USA. 1998; 95:1944-1949. [PubMed: 9465122]

5. Kaplan B, Sherman T, Fromm H. Cyclic nucleotide-gated channels in plants. FEBS Lett. 2007; 581:2237-2246. [PubMed: 17321525] 
6. Clough SJ, Fengler KA, Yu I-C, Lippok B, Smith RK Jr, Bent AF. The Arabidopsis dnd1 "defense, no death" gene encodes a mutated cyclic nucleotide-gated ion channel. Proc Natl Acad Sci USA. 2000; 97:9323-9328. [PubMed: 10900264]

7. Moeder W, Urquhart W, Ung H, Yoshioka K. The role of cyclic nucleotide-gated ion channels in plant immunity. Mol Plant. 2011; 4:442-452. [PubMed: 21459831]

8. Hua BG, Mercier RW, Leng Q, Berkowitz GA. Plants do it differently. A new basis for potassium/ sodium selectivity in the pore of an ion channel. Plant Physiol. 2003; 132:1353-1361. [PubMed: 12857817]

9. Leng Q, Mercier RW, Yao W, Berkowitz GA. Cloning and first functional characterization of a plant cyclic nucleotide-gated cation channel. Plant Physiol. 1999; 121:753-761. [PubMed: 10557223]

10. Frietsch S, Wang YF, Sladek C, Poulsen LR, Romanowsky SM, Schroeder JI, Harper JF. A cyclic nucleotide-gated channel is essential for polarized tip growth of pollen. Proc Natl Acad Sci USA. 2007; 104:14531-14536. [PubMed: 17726111]

11. Ali R, Ma W, Lemtiri-Chlieh F, Tsaltas D, Leng Q, von Bodman S, Berkowitz GA. Death don't have no mercy and neither does calcium: Arabidopsis CYCLIC NUCLEOTIDE GATED CHANNEL2 and innate immunity. Plant Cell. 2007; 19:1081-1095. [PubMed: 17384171]

12. Guo KM, Babourina O, Christopher DA, Borsic T, Rengel Z. The cyclic nucleotide-gated channel AtCNGC10 transports $\mathrm{Ca}^{2+}$ and $\mathrm{Mg}^{2+}$ in Arabidopsis. Physiol Plant. 2010; 139:303-312. [PubMed: 20210874]

13. Lam HM, Chiu J, Hsieh MH, Meisel L, Oliveira IC, Shin M, Coruzzi G. Glutamate-receptor genes in plants. Nature. 1998; 396:125-126. [PubMed: 9823891]

14. Lacombe B, Becker D, Hedrich R, DeSalle R, Hollmann M, Kwak JM, Schroeder JI, Novère NL, Nam HG, Spalding EP, et al. The identity of plant glutamate receptors. Science. 2001; 292:14861487. [PubMed: 11379626]

15. Traynelis SF, Wollmuth LP, McBain CJ, Menniti FS, Vance KM, Ogden KK, Hansen KB, Yuan HJ, Myers SJ, Dingledine R. Glutamate receptor ion channels: structure, regulation, and function. Pharmacol Rev. 2010; 62:405-496. [PubMed: 20716669]

16. Dennison KL, Spalding EP. Glutamate-gated calcium fluxes in Arabidopsis. Plant Physiol. 2000; 124:1511-1514. [PubMed: 11115867]

17. Meyerhoff O, Müller K, Roelfsema MRG, Latz A, Lacombe B, Hedrich R, Dietrich P, Becker D. AtGLR3. 4, a glutamate receptor channel-like gene is sensitive to touch and cold. Planta. 2005; 222:418-427. [PubMed: 15864638]

18. Davenport R. Glutamate receptors in plants. Ann Bot. 2002; 90:549-557. [PubMed: 12466095]

19•. Tapken D, Hollmann M. Arabidopsis thaliana glutamate receptor ion channel function demonstrated by ion pore transplantation. J Mol Biol. 2008; 383:36-48. Animal iGluR subunits express reasonably well in Xenopus oocytes but plant GLRs do not. The authors transplant the pore region of plant GLRs into an animal iGluR, express the chimeric channel in oocytes, and infer ion transport properties of the native GLR from the measurements. [PubMed: 18625242]

20. Qi Z, Stephens NR, Spalding EP. Calcium entry mediated by GLR3. 3, an Arabidopsis glutamate receptor with a broad agonist profile. Plant Physiol. 2006; 142:963-971. [PubMed: 17012403]

21. Stephens NR, Qi Z, Spalding EP. Glutamate receptor subtypes evidenced by differences in desensitization and dependence on the GLR3.3 and GLR3.4 genes. Plant Physiol. 2008; 146:529538. Authors interpret electrophysiological results obtained from Arabidopsis glr3.3 and glr3.4 mutants as evidence that functional GLRs in the plant are heteromers of subunits having different agonist specificities. [PubMed: 18162597]

22. Roy SJ, Gilliham M, Berger B, Essah PA, Cheffings C, Miller AJ, Davenport RJ, Liu L-H, Skynner MJ, Davies JM, et al. Investigating glutamate receptor-like gene co-expression in Arabidopsis thaliana. Plant Cell Environ. 2008; 31:861-871. [PubMed: 18284583]

23•. Michard E, Lima PT, Borges F, Silva AC, Portes MT, Carvalho JE, Gilliham M, Liu LH, Obermeyer G, Feijó JA. Glutamate receptor-like genes form $\mathrm{Ca}^{2+}$ channels in pollen tubes and are regulated by pistil D-serine. Science. 2011; 332:434-437. Authors provide evidence that GLR1.2 contributes to $\mathrm{Ca}^{2+}$ signals in pollen tubes but the data do not significantly advance the case for GLRs forming $\mathrm{Ca}^{2+}$ channels. [PubMed: 21415319] 
24. Nakagawa Y, Katagiri T, Shinozaki K, Qi Z, Tatsumi H, Furuichi T, Kishigami A, Sokabe M, Kojima I, Sato S, et al. Arabidopsis plasma membrane protein crucial for $\mathrm{Ca}^{2+}$ influx and touch sensing in roots. Proc Natl Acad Sci USA. 2007; 104:3639-3644. [PubMed: 17360695]

25•. Yamanaka T, Nakagawa Y, Mori K, Nakano M, Imamura T, Kataoka H, Terashima A, Iida K, Kojima I, Katagiri T, et al. MCA1 and MCA2 that mediate $\mathrm{Ca}^{2+}$ uptake have distinct and overlapping roles in Arabidopsis. Plant Physiol. 2010; 152:1284-1296. Authors use genetic manipulation of expression to show two membrane proteins capable of rescuing a yeast $\mathrm{Ca}^{2+}$ uptake mutant have diverse effects on growth in specific ionic conditions. [PubMed: 20097794]

26. Peiter E. The plant vacuole: emitter and receiver of calcium signals. Cell Calcium. 2011 in press. 10.1016/j.ceca.2011.02.002

27. Ishibashi K, Suzuki M, Imai M. Molecular cloning of a novel form (two-repeat) protein related to voltage-gated sodium and calcium channels. Biochem Biophys Res Commun. 2000; 270:370-376. [PubMed: 10753632]

28. Hedrich R, Neher E. Cytoplasmic calcium regulates voltage-dependent ion channels in plant vacuoles. Nature. 1987; 329:833-836.

29. Ward JM, Schroeder JI. Calcium-activated $\mathrm{K}^{+}$channels and calcium-induced calcium release by slow vacuolar ion channels in guard cell vacuoles implicated in the control of stomatal closure. Plant Cell. 1994; 6:669-683. [PubMed: 12244253]

30. Furuichi T, Cunningham KW, Muto S. A putative two pore channel AtTPC1 mediates $\mathrm{Ca}^{2+}$ flux in Arabidopsis leaf cells. Plant Cell Physiol. 2001; 42:900-905. [PubMed: 11577183]

31. Peiter E, Maathuis FJM, Mills LN, Knight H, Pelloux J, Hetherington AM, Sanders D. The vacuolar $\mathrm{Ca}^{2+}$-activated channel TPC1 regulates germination and stomatal movement. Nature. 2005; 434:404-408. [PubMed: 15772667]

32. Ranf S, Wünnenberg P, Lee J, Becker D, Dunkel M, Hedrich R, Scheel D, Dietrich P. Loss of the vacuolar cation channel, AtTPC1, does not impair $\mathrm{Ca}^{2+}$ signals induced by abiotic and biotic stresses. Plant J. 2008; 53:287-299. [PubMed: 18028262]

33. Islam MM, Munemasa S, Hossain MA, Nakamura Y, Mori IC, Murata Y. Roles of AtTPC1, Vacuolar Two Pore Channel 1, in Arabidopsis stomatal closure. Plant Cell Physiol. 2010; 51:302311. [PubMed: 20061305]

34. Beyhl D, Hörtensteiner S, Martinoia E, Farmer EE, Fromm J, Marten I, Hedrich R. The fou 2 mutation in the major vacuolar cation channel TPC1 confers tolerance to inhibitory luminal calcium. Plant J. 2009; 58:715-723. [PubMed: 19298454]

35. Ward JM, Maser P, Schroeder JI. Plant ion channels: gene families, physiology, and functional genomics analyses. Annu Rev Physiol. 2009; 71:59-82. [PubMed: 18842100]

36. Shigaki T, Rees I, Nakhleh L, Hirschi KD. Identification of three distinct phylogenetic groups of CAX cation/proton antiporters. J Mol Evol. 2006; 63:815-825. [PubMed: 17086450]

37. Baxter I, Tchieu J, Sussman MR, Boutry M, Palmgren MG, Gribskov M, Harper JF, Axelsen KB. Genomic comparison of P-type ATPase ion pumps in Arabidopsis and rice. Plant Physiol. 2003; 132:618-628. [PubMed: 12805592]

38. Kim Y-Y, Choi H, Segami S, Cho H-T, Martinoia E, Maeshima M, Lee Y. AtHMA1 contributes to the detoxification of excess $\mathrm{Zn}$ (II) in Arabidopsis. Plant J. 2009; 58:737-753. [PubMed: 19207208]

39. Moreno I, Norambuena L, Maturana D, Toro M, Vergara C, Orellana A, Zurita-Silva A, Ordenes VR. AtHMA1 is a thapsigargin-sensitive $\mathrm{Ca}^{2+}$ /heavy metal pump. J Biol Chem. 2008; 283:96339641. [PubMed: 18252706]

40. Kudla J, Batistic O, Hashimoto K. Calcium signals: the lead currency of plant information processing. Plant Cell. 2010; 22:541-63. [PubMed: 20354197]

41. Brini M, Carafoli E. Calcium pumps in health and disease. Physiol Rev. 2009; 89:1341-1378. [PubMed: 19789383]

42•. Qudeimata E, Faltusza AMC, Wheeler G, Lang D, Brownlee C, Reskia R, Frank W. A PIIB-type $\mathrm{Ca}^{2+}$-ATPase is essential for stress adaptation in Physcomitrella patens. Proc Natl Acad Sci USA. 2008; 105:19555-19560. Authors show that loss of a vacuolar $\mathrm{Ca}^{2+}$-ATPase increases the magnitude and duration of a salt-stress triggered $\mathrm{Ca}^{2+}$-signal. [PubMed: 19050080] 
43•. Zhu X, Caplan J, Mamillapalli P, Czymmek K, Dinesh-Kumar SP. Function of endoplasmic reticulum calcium ATPase in innate immunity-mediated programmed cell death. EMBO J. 2010; 29:1007-1018. Authors show that antisense suppression of an endomembrane $\mathrm{Ca}^{2+}$-ATPase results in an elicitor triggered $\mathrm{Ca}^{2+}$-signal with higher magnitude and duration. [PubMed: 20075858]

44•. Boursiac Y, Lee SM, Romanowsky S, Blank R, Sladek C, Chung WS, Harper JF. Disruption of the vacuolar calcium-ATPases in Arabidopsis results in the activation of a salicylic aciddependent programmed cell death pathway. Plant Physiol. 2010; 154:1158-1171. Authors show that a loss of vacuolar $\mathrm{Ca}^{2+}$-ATPases in mesophyll cells results in a lesion mimic phenotype. [PubMed: 20837703]

45. Du L, Ali GS, Simons KA, Hou J, Yang T, Reddy ASN, Poovaiah BW. $\mathrm{Ca}^{2+} /$ calmodulin regulates $^{2}$ salicylic-acid-mediated plant immunity. Nature. 2009; 457:1154-1158. [PubMed: 19122675]

46. Wang L, Tsuda K, Sato M, Cohen JD, Katagiri F, Glazebrook J. Arabidopsis CaM binding protein CBP60g contributes to MAMP-induced SA accumulation and is involved in disease resistance against Pseudomonas syringae. PLoS Pathog. 2009; 5:e1000301. [PubMed: 19214217]

47. Conn SJ, Gilliham M, Athmana A, Schreiber AW, Baumann U, Moller I, Cheng N-H, Stancombe M, Hirschi KD, Webb AAR, et al. Cell-specific vacuolar calcium storage mediated by CAX1 regulates apoplastic calcium concentration, gas exchange, and plant productivity in Arabidopsis. Plant Cell. 2011; 23:240-257. Authors show that loss of vacuolar $\mathrm{Ca}^{2+}$-ATPases do not change the accumulation of $\mathrm{Ca}^{2+}$ in Arabidopsis meosphyl cells, providing support that a lesion mimic phenotype in an aca4/11 knockout is due to a change in signaling as opposed to a change in calcium "nutrition". [PubMed: 21258004]

48. Coe H, Michalak M. Calcium binding chaperones of the endoplasmic reticulum. Gen Physiol Biophys. 2009; 28:F96-F103. [PubMed: 20093733]

49. Periz G, Fortini ME. $\mathrm{Ca}^{2+}$-ATPase function is required for intracellular trafficking of the Notch receptor in Drosophila. EMBO J. 1999; 18:5983-5993. [PubMed: 10545110]

50. Pittman JK, Sreevidya CS, Shigaki T, Ueoka-Nakanishi H, Hirschi KD. Distinct N-terminal regulatory domains of $\mathrm{Ca}^{2+} / \mathrm{H}^{+}$antiporters. Plant Physiol. 2002; 130:1054-1062. [PubMed: 12376668]

51. Gaymard F, Pilot G, Lacombe B, Bouchez B, Bruneau D, Boucherez J, Michaux-Ferrière N, Thibaud J-B, Sentenac H. Identification and disruption of a plant Shaker-like outward channel involved in $\mathrm{K}^{+}$release into the xylem sap. Cell. 1998; 94:647-655. [PubMed: 9741629]

52. Lan W-Z, Wang W, Wang S-M, Li L-G, Buchanan BB, Lin H-X, Gao J-P, Luan S. A rice highaffinity potassium transporter (HKT) conceals a calcium-permeable cation channel. Proc Natl Acad Sci USA. 2010; 107:7089-7094. [PubMed: 20351263]

53. Laohavisit A, Brown AT, Cicuta P, Davies JM. Annexins: components of the calcium and reactive oxygen signaling network. Plant Physiol. 2010; 2010(152):1824-1829. [PubMed: 20154100]

54. Teardo E, Formentin E, Segalla A, Giacometti GM, Marin O, Zanetti M, Schiavo FL, Zoratti M, Szabò I. Dual localization of plant glutamate receptor AtGLR3. 4 to plastids and plasma membrane. Biochim Biophys Acta - Bioenergetics. 2011; 1807:359-367.

55. Kurusu T, Yagala T, Miyao A, Hirochika H, Kuchitsu K. Identification of a putative voltage-gated $\mathrm{Ca}^{2+}$ channel as a key regulator of elicitor-induced hypersensitive cell death and mitogenactivated protein kinase activation in rice. Plant J. 2005; 42:798-809. [PubMed: 15941394]

56. Hashimoto K, Saito M, Iida H, Matsuoka H. Evidence for the plasma membrane localization of a putative voltage-dependent $\mathrm{Ca}^{2+}$ channel, OsTPC1, in rice. Plant Biotechnol. 2005; 22:235-239.

57. Hepler PK, Winship LJ. Calcium at the cell wall-cytoplast interface. J Integr Plant Biol. 2010; 52:147-160. [PubMed: 20377677] 


\section{Highlights}

- Heterologous expression and in planta mutant data best define a transport function

- $\quad$ Each $\mathrm{Ca}^{2+}$ influx candidate requires more experimental testing

- Regulation of influx and efflux pathways control $\mathrm{Ca}^{2+}$ transients

- Endomembrane $\mathrm{Ca}^{2+}$-pumps can function to suppress a $\mathrm{Ca}^{2+}$ cell death signature 


\section{Pump Channel Antiporter}
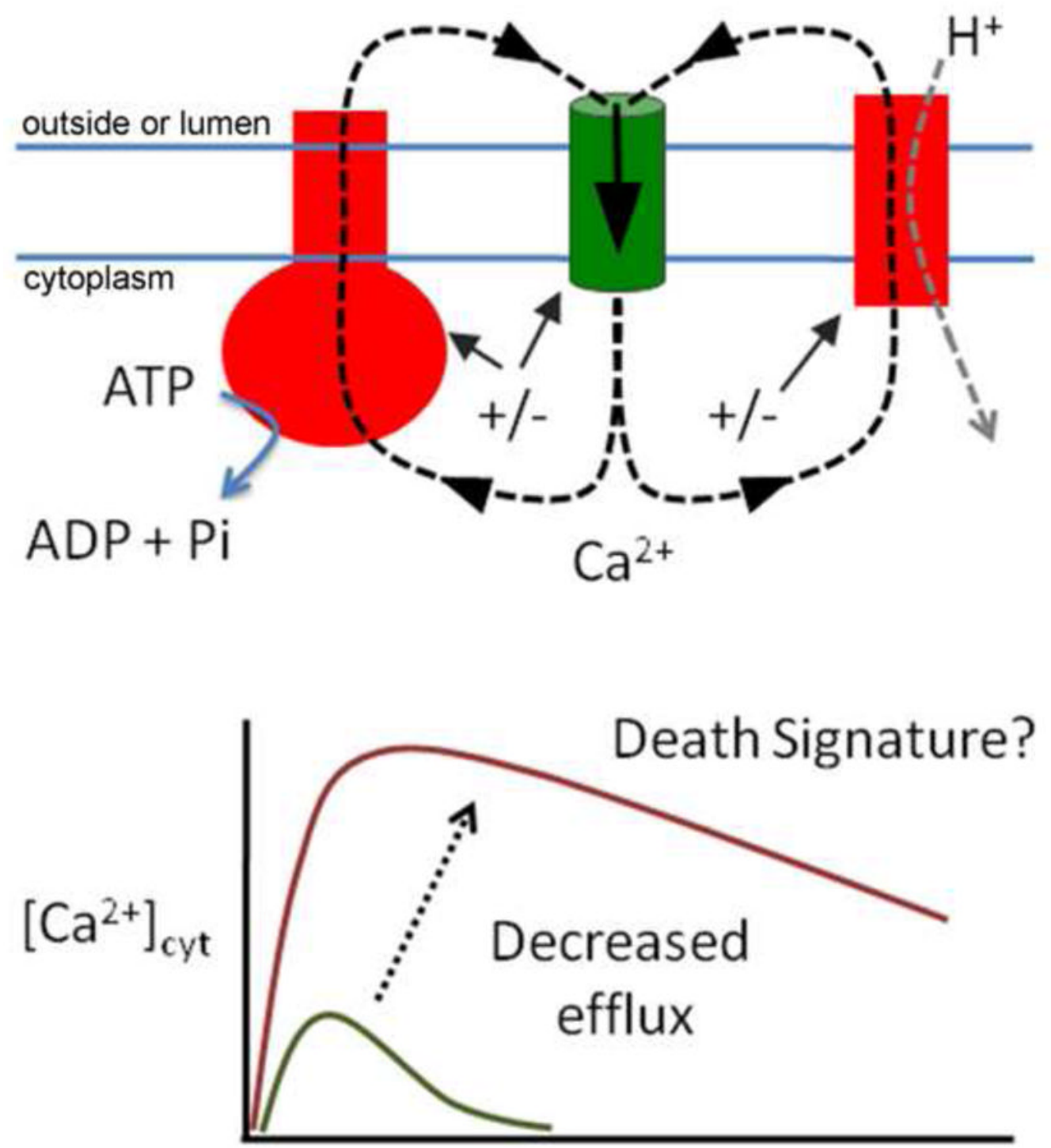

Time

Figure 1.

$\mathrm{Ca}^{2+}$ circuits are created with different membrane systems by the coordinated regulation of influx and efflux pathways (top). Evidence indicates that a loss of specific endomembrane efflux pathways can result in a greater magnitude and prolonged duration of a $\mathrm{Ca}^{2+}$ signature that correlates with triggering cell death (bottom). Not indicated in the figure is the role of $\mathrm{Ca}^{2+}$ buffering, which can affect flux rates and magnitudes [57]. 